\title{
Cloning $\operatorname{sod} N$
}

The $\operatorname{sodN}$ gene from $\mathrm{H} 15$ forward was cloned out of the pET3a-SODN vector using PCR amplification the primers 5'- GGTATTGAGGGTCGCCACTGCGACCTGCCCTG -3' (5'SODNH15) and 5'-AGAGGAGAGTTAGAGCCCTTTGTTAGCAGCCGG-3' (3'SODNU). The PCR product was purified from a $1 \%$ agarose gel. Treatment of the PCR product with T4 DNA polymerase created overhangs complimentary to the Ligation Independent Cloning (LIC) vector pET30 Xa/LIC (Novagen ${ }^{\mathrm{TM}}$ ). The insert was annealed to the vector and NovaBlue $\left(\right.$ Novagen $\left.^{\mathrm{TM}}\right)$ competent cells were transformed with the pET30 $\mathrm{Xa} / \mathrm{LIC}$ plasmid containing the sodN gene. The NovaBlue cells were plated on LB media containing 34 • g/ml kanamycin (kan) and grown overnight at $37^{\circ} \mathrm{C}$. Plasmid mini preps (Qiagen) were performed after single colonies were grown in $3 \mathrm{ml}$ of LB kan media overnight. Bl21 (DE3) pLysS (Novagen ${ }^{\mathrm{TM}}$ ) competent cells were transformed with the plasmid pET-30Xa/LIC-SODNH15 (pSODNH15) and were plated and grown overnight with shaking at $37^{\circ} \mathrm{C}$ on LB media containing kan and $30 \bullet \bullet \mathrm{g} / \mathrm{ml}$ chloramphenicol (cam). Single colonies were grown overnight in $3 \mathrm{ml}$ cultures (LB kan/cam) and diluted 1:100 in $10 \mathrm{ml}$ of fresh media. Cells were grown at $37^{\circ} \mathrm{C}$ to an OD $550 \mathrm{~nm}$ of 0.6 and induced with isopropyl- $\beta$-D-thiogalactoside (IPTG), final concentration $0.8 \mathrm{mM}$. After 3 hours the cells were harvested via centrifugation and SDS-PAGE was run to determine expression of the target fusion protein (Figure 1). Plasmids producing proteins of the appropriate molecular weight $(18 \mathrm{kDa})$ were submitted to the University of Massachusetts DNA sequencing facility to confirm the deduced amino acid sequence.

\section{Expression and purification of fusion protein}

Single colonies were grown in $10 \mathrm{ml}$ culture ( $\mathrm{LB}$ cam/kan) overnight at $37^{\circ} \mathrm{C}$ with shaking then added to 1 liter of pre-warmed fresh media. Cultures were grown to an OD of 0.6 and induced $(0.8 \mathrm{mM}$ IPTG) for 3 hours. Cells were harvested by centrifugation, resuspended in $50 \mathrm{ml}$ of Ni-NTA bind buffer (10 mM imidazole, $50 \mathrm{mM}$ sodium phosphate, $300 \mathrm{mM}$ sodium chloride $\mathrm{pH} 8.0$ ) with 1 mM phenylmethylsulfonyl fluoride (PMSF), and frozen at $-80^{\circ} \mathrm{C}$. Aliquots of cells were thawed, $100 \mu$ of DNAse I solution ( $10 \mathrm{mg} / \mathrm{ml}$ DNAse I, $10 \mathrm{mM}$ magnesium chloride, $20 \mathrm{mM}$ Tris pH 7.5, $40 \%$ glycerol) was added and incubated at $37^{\circ} \mathrm{C}$ for $25 \mathrm{~min}$ or until the viscosity of the solution was significantly reduced. All chromatographic purifications employed a Pharmacia FPLC with LCC-500 controller and a UV 
detector. The cell lysate was then loaded onto a column (Pharmacia HR10) containing Ni-NTA His•Bind Superflow ${ }^{\mathrm{TM}}$ resin $\left(\right.$ Novagen $\left.^{\mathrm{TM}}\right)$ at $1.5 \mathrm{ml} / \mathrm{min}$ with bind buffer. The loading was monitored at $280 \mathrm{~nm}$, when the signal returned to the baseline a step gradient was applied of $30 \%$ elute buffer $(250 \mathrm{mM}$ imidazole, $50 \mathrm{mM}$ sodium phosphate, $300 \mathrm{mM}$ sodium chloride, $\mathrm{pH}$ 8.0) and the column was washed with 7 volumes of buffer. Following the wash step the fusion protein was eluted from the column with $100 \%$ elute buffer. The eluted protein was then dialyzed against 4 liters of $20 \mathrm{mM}$ Tris buffer $\mathrm{pH} 8.5$ containing $0.5 \mathrm{mM}$ PMSF using 7000 MWCO SnakeSkin ${ }^{\circledast}$ pleated dialysis tubing (Pierce). Subsequently the fusion protein was dialyzed 3 times against 4 liters Factor Xa cleavage buffer $(5 \mathrm{mM}$ calcium chloride, $50 \mathrm{mM}$ Tris, $100 \mathrm{mM}$ sodium chloride, $\mathrm{pH}$ 8.0) with $0.25 \mathrm{mM}$ PMSF.

\section{Factor Xa cleavage}

Fusion protein in factor Xa cleavage buffer was divided into $1 \mathrm{ml}$ aliquots. Factor Xa was added to the buffer at a concentration of $1 \mathrm{unit} / 50 \mu \mathrm{g}$ of fusion protein. The cleavage reaction was left at $4^{\circ} \mathrm{C}$ for 4 days. Cleavage was monitored by SDS-PAGE (Figure 1). At the completion of the factor Xa reaction the $1 \mathrm{ml}$ aliquots were combined and dialyzed against $20 \mathrm{mM}$ Tris $\mathrm{pH} 8.5$ exhaustively. Anion exchange chromatography (Pharmacia FPLC-Mono Q) using Tris buffer at $\mathrm{pH} 8.5$ with a $0.35 \mathrm{M}$ sodium chloride gradient over $20 \mathrm{~min}$ and a flow rate of $0.5 \mathrm{ml} / \mathrm{min}$ gave pure apo-NiSOD in the first fractions off the column. The expression of the fusion protein and correct processing to yield apo-NiSOD was determined by the molecular weights of the products (Calc'd for the fusion protein: 18,170 Da, Found ESI-MS 18,172 Da, SDS-PAGE, 18 kDa) (Figure 2) (Calc'd for apo-NiSOD: 13,201 Da; Found: ESI-MS 13,202 Da, SDSPAGE, $13 \mathrm{kDa}$ ) (Figure 3) and by Edman N-terminal peptide sequencing (Midwest Analytical, Inc., St. Louis MO) confirmed that the protein had the WT His N-terminus (HCDLPCGV).

\section{Reconstitution of NiSOD}

Reconstitution of the reduced, recombinant apo-NiSOD was achieved by addition of a 10 fold excess of dithiothreitol (DTT) and subsequent dialysis with $1.0 \mathrm{mM} \mathrm{NiCl}$, all under anaerobic conditions (Coy chamber). This resulted in enzyme that contained 0.88 equiv. of Ni per subunit (Bradford protein analysis, graphite furnace AA Ni analysis), was hexameric ${ }^{1}$ and spontaneously developed both the $378 \mathrm{~nm}$ UV-vis absorption and EPR spectrum upon exposure to air. 


\section{Mutagenesis}

Amino acid substitutions were made by site-directed mutagenesis using mutagenic primers. Two PCR fragments were required to create the M28L mutation ${ }^{2}$. Reaction A used the primers 5'GGTATTGAGGGTCGCCACTGCGACCTGCCCTG -3' and 5'-TTTTTCAGAAGATCTTGTCGATCTG -3' with pSODNH15. Reaction B used the primers 5' - GGCCGTCCAGGAGAAGCTGGC CGGCAACGACGACG-3' and 3'SODNU with pSODNH15. The products of PCR A and B were gel purified (1\% agarose) and used in combination with primers 5'SODNH15 and 3'SODNU in a third PCR. The PCR product was gel purified (1\% agarose) and the procedure for wild type NiSOD was followed as described previously. Mutation of H1Q was achieved through PCR of pSODNH15 with 5'GGTATTGAGGGTCGCCACTGCCAGCTGCCCTG-3' and 3'SODNU. The product was gel purified (1\% agarose) and the procedure for the wild type protein was followed as described previously.

The expression of the mutant fusion protein and correct processing to yield apo-M28L-NiSOD was confirmed by DNA sequencing and by the molecular weights of the products (Calc'd for the fusion protein: 18,152 Da; ESI-MS Found: 18,152 Da) The recombinant enzyme contained 1.1 equiv. of Ni per subunit. The expression of the mutant fusion protein and correct processing to yield apo-H1Q-NiSOD was confirmed by DNA sequencing and by the molecular weights of the products (Calc'd for the fusion protein: 18,160, SDS-PAGE, $18 \mathrm{kDa}$; Calc'd for apoH1Q-NiSOD: $13192 \mathrm{Da}$; ESI-MS Found: $13190 \mathrm{Da})$. The recombinant enzyme contained 0.6 equiv. of $\mathrm{Ni}$ per subunit.

\section{XAS}

X-ray absorbtion spectroscopy was performed at the national synchrotron light source as previous described. ${ }^{3}$ Figure 4 displays Ni k-edge XANES spectra obtained for wild type and mutant NiSODs. 


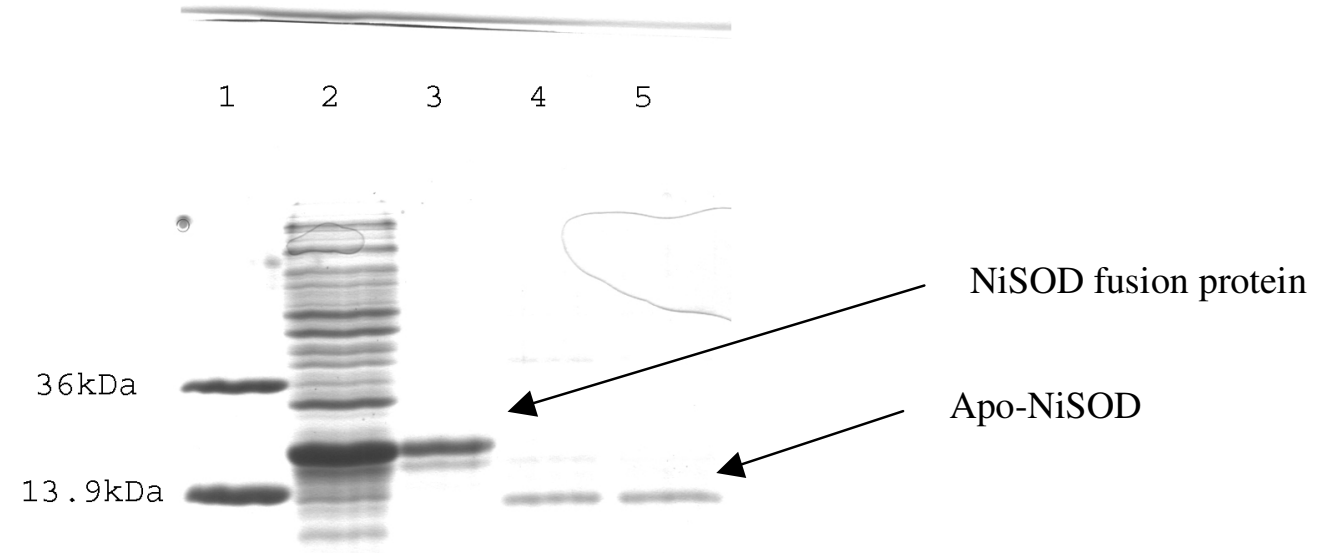

Figure 1. SDS-PAGE 15\% from left to right 1) Molecular weight markers $13.9 \mathrm{kDa}$ and $36 \mathrm{kDa}$ 2) extract from cells induced with IPTG 3) Fusion protein after Ni-NTA column purification 4) Fusion protein treated with Factor Xa 5) apo NiSOD after Mono-Q anion exchange column chromatography.

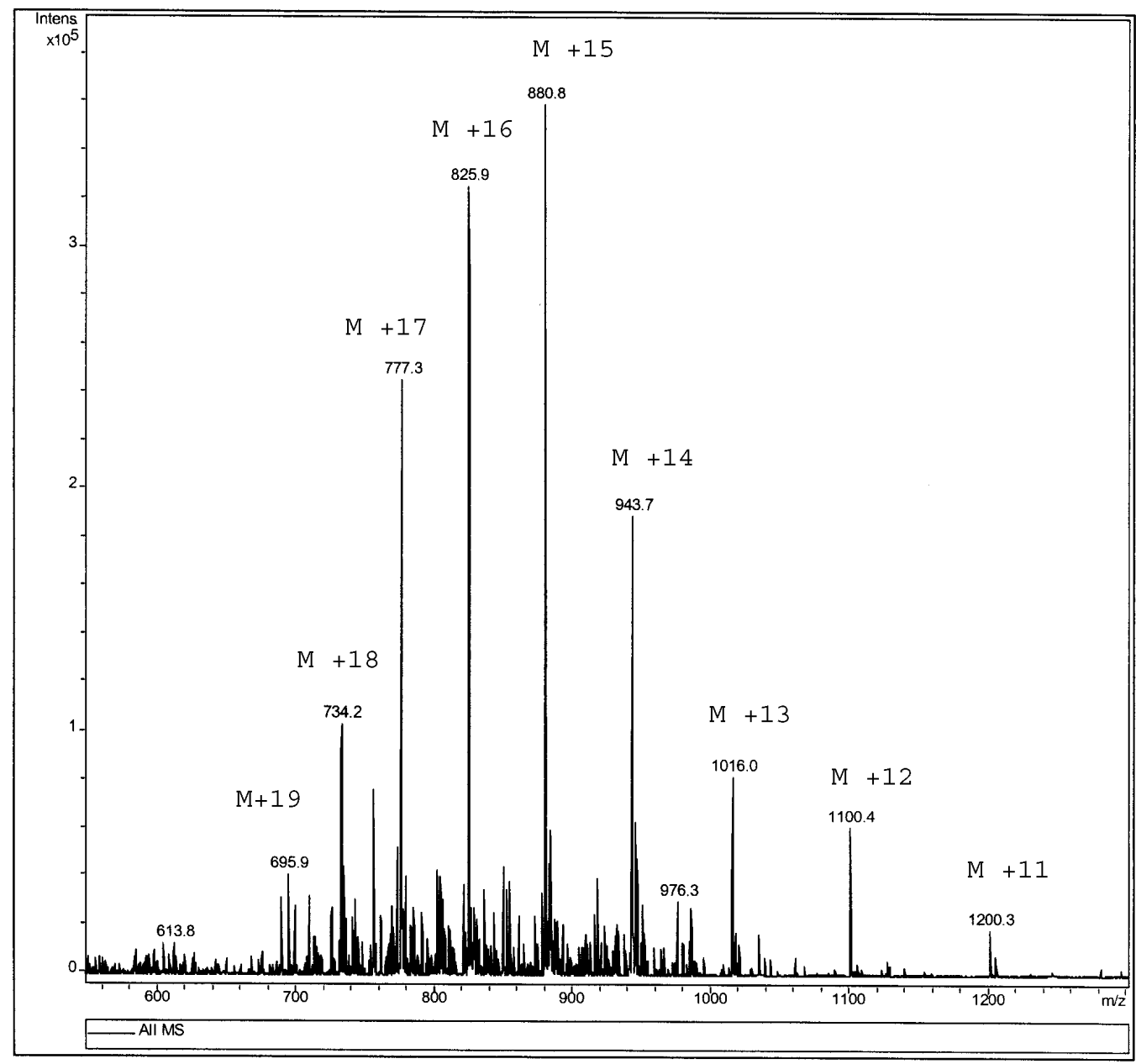


Figure 2. ESI-MS of the wild type NiSOD fusion protein.

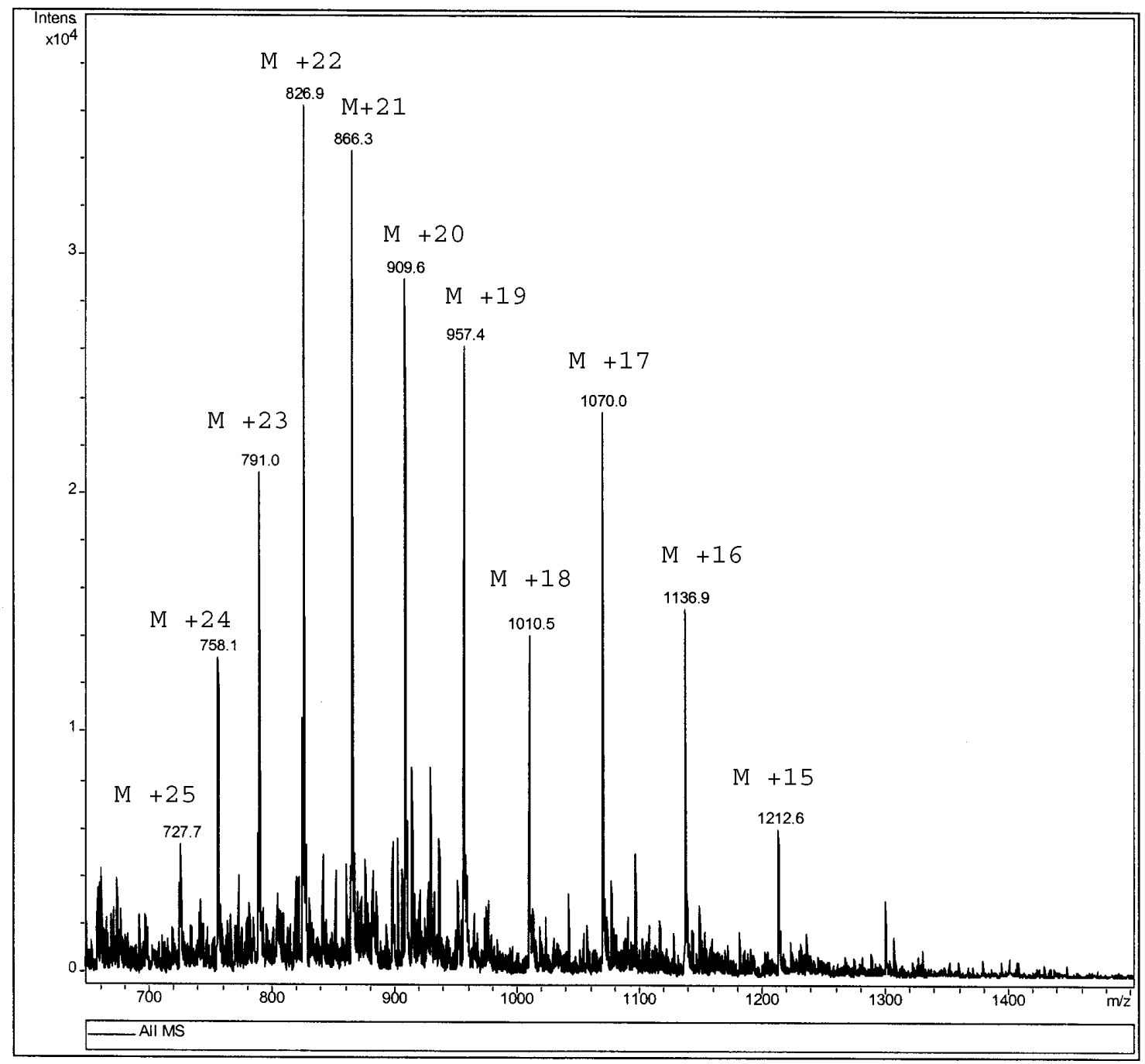

Figure 3. ESI-MS of the WT-NiSOD protein. 


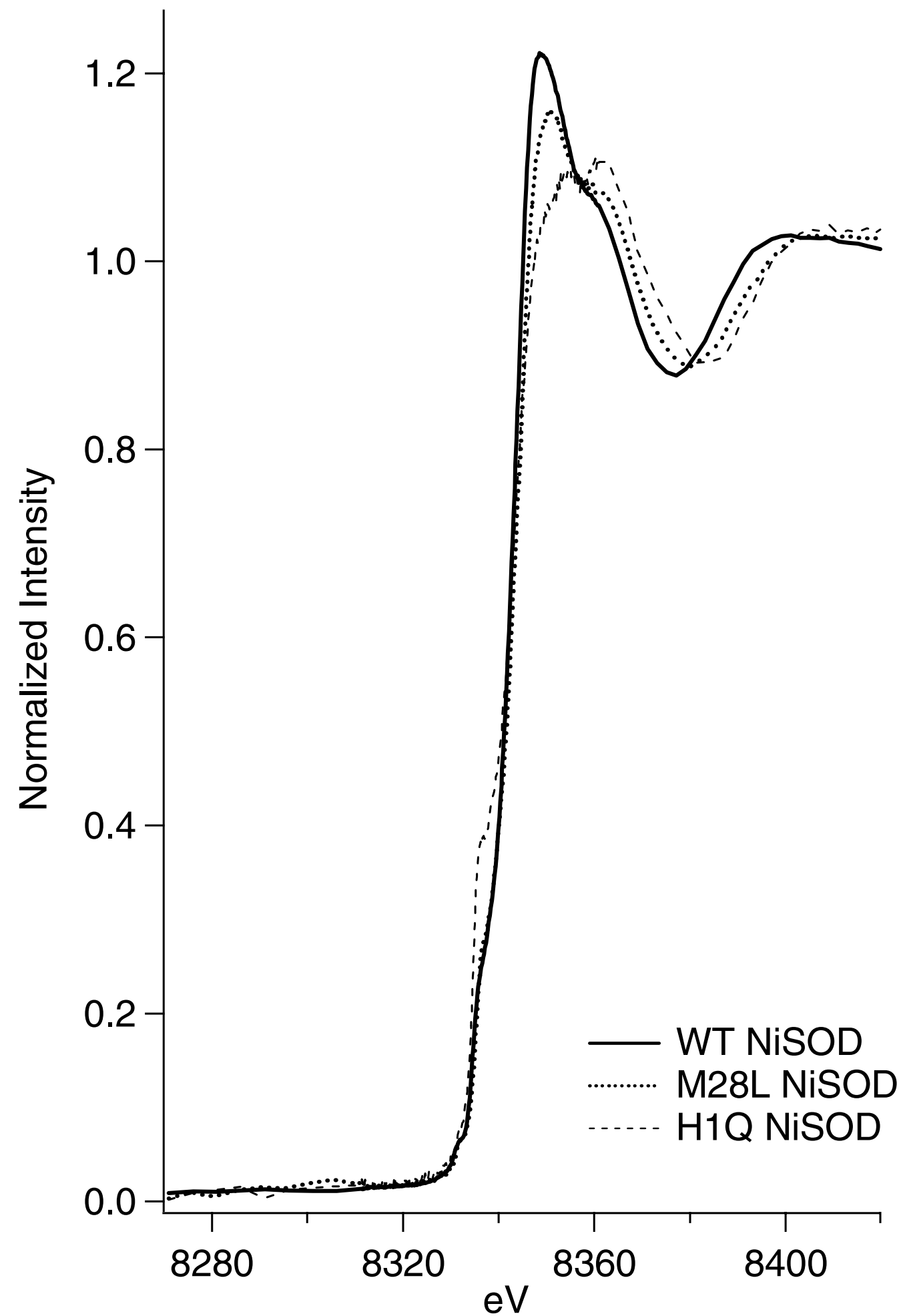

Figure 4. XANES spectra of Streptomyces coelicolor NiSODs. Wild type NiSOD (solid line), M28L NiSOD (dotted line), and H1Q NiSOD (dashed line). 
(1) Neimoth-Anderson, J.; Pinkham, J. L.; Maroney, M. J., Unpulished results.

(2) Mikaelian, I.; Sergeant, A. Nucleic Acids Res. 1992, 20, 376-376.

(3) Carrington, P. E.; Chivers, P. T.; Al-Mjeni, F.; Sauer, R. T.; Maroney, M. J. Nature Structural Biology 2003, 10, 126-130. 